\title{
Institutional Arrangement of Agriculture Development in Indonesia: Lesson Learn from Korea through 6th Order of Industrial Agriculture System
}

\author{
Adhitya Wardhono*, Rudi Wibowo ${ }^{2}$ \\ *Faculty of Economics and Busines - Univeristy of Jember; ${ }^{2}$ Postgraduate Program- Univeristy of Jember
}

\begin{abstract}
The development of economy in the recent years has successfully changed the Indonesian economy from agricultural economy to Industrial economy. However, when the sectoral output contribution decreases sharply, it does not mean that agriculture sector becomes unimportant factor in the Indonesian Economy. In recent years, the data shows that the agricultural sector still absorbs high employment compared to other sectors, which amounted to $30.9 \%$ of the total 121.7 million workforce. Increasing instability in the management of the agricultural industry and increasing population resulted in reduced regional vitality and community productivity. Therefore, through the policy concept of The Sixth Order Industry, it is important for the Indonesian government to build policy support and measures to promote the local economy in maintaining the welfare of the agricultural community. The purpose of this study is to determine the priority of policy objectives and support related to the 6th-order agricultural industrialization policy and identify the rules of agricultural institutions in Indonesia through the concept of the 6th-order agricultural industrialization policy. The method used study of literature and SWOT. Based on the results of the analysis, it can be seen that marketing and financial support are the most important means among several policy tools in achieving the goals of The Sixth Order Industry. Improving governance, agricultural management from upstream to downstream, and increasing cooperation between farmers, industry and banking are the keys to the success of agricultural development in Indonesia in order to achieve food sovereignty.
\end{abstract}

Keyword: Institutional Arrangement, Agriculture, The Sixth Order Industry

\section{Introduction}

Economic development over the last few years has succeeded in changing the structure of the Indonesian economy from an economy based to the agricultural sector

to become an economy based on the industrial sector. However, when the contribution of sectoral output has declined sharply, it does not mean that the agricultural sector is no longer an important factor in the Indonesian economy. Data from 2015 shows that the agricultural sector still absorbs a fairly high workforce of $30.9 \%$ of the total 121.7 million workforce. While the industrial sector only absorbs $17.9 \%$. The remaining $51.2 \%$ is absorbed by the service sector [1]. This also shows that structural inequality problems have occurred as a result of the industrialization process taken during the last four decades (starting in the early 1970s).
Structural changes in economic output from the agricultural sector to the industrial sector were not followed by changes in the employment structure. Research conducted by [2] [3] classifies countries in the world that have succeeded in industrializing and which are not yet in two categories, namely in terms of output and employment. The results of the classification are arranged in a matrix, Indonesia falls into the category of low middle-income countries that have succeeded in industrializing in terms of output but have not succeeded in terms of employment. Once again, the role of output in the agricultural sector has dropped dramatically but this sector is still 'inhabited' by quite a number of households or labor. So from this problem a solution is needed to improve the quality of agricultural output in order to increase the income of farmers and the agricultural sector industry.

Furthermore, a study conducted by [2] and [4] explained that the agricultural sector plays an important role in the

* Corresponding author: adhitya.wardhono@unej.ac.id 
economy, such as sources of income and employment opportunities for rural residents where most of the rural population has main livelihoods as farmers, food producers to meet the basic needs of a growing population, stimulating the industrialization process (especially for industrialization that has a fairly large relationship with the agricultural sector), contributors to the country's foreign exchange because the agricultural sector produces tradable and market-oriented agricultural products exports, and as a market for nonfarm sector products and services.

Based on these problems, the concept of The 6th Order Industry emerged in South Korea and Japan. This concept explains the relationship between primary, secondary and tertiary industries in order to improve food security through increasing farmer income [5] [6] [7]. Increased instability in the management of the agricultural industry and increase in population has led to a reduction in regional vitality and community productivity. Therefore, it is important for the Indonesian government to build policy support and measures to promote the local economy in maintaining the welfare of the agricultural community. The purpose of this study is to determine Indonesia's agricultural policy strategy through the 6th order agricultural industrialization policy concept using a SWOT analysis.

\section{LITERATURE REVIEW}

Food security which is the aim of "The Sixth Order Industry" consists of several important components, namely: Affordability, Availability, Quality and Safety [3]. All these components are strongly influenced by shifts in demand (demand shifters), such as population growth, increasing middle class society, urbanization, shifting consumer spending towards high value commodities, demand for fast food and beverages[6]. Besides food security is also influenced by supply shifters such as the increasingly limited agricultural land, the more advanced innovations in agriculture and food, the increasingly scarce water availability, climate change and the less protection in the agriculturalmarket.

In "The Sixth Order Industry" it can be said that the use of "irregular agricultural products" as inputs for production is a key factor in the success of an agricultural industry. In agricultural products, there are two types of products namely "standardized products" for sale and "irregular products" that are not for sale [7][8]. Although irregular products are not the same as standardized products in terms of food safety, taste, odor, texture, etc., foods processed by the same product (both irregular and standardized) can be sold as processing materials, but most of the irregular products are discarded because of color or size [8][9][10]. Therefore, farmers want to sell irregular products at reasonable prices, but the food industry wants to buy products that are standardized and suitable for mass processing.

Because of this mismatch, farmers must process irregular products themselves if they want to get added value from these products. However, irregular products exist during the harvest season and product distribution, so farmers are unable to process them and dispose of them by force. Irregular products not only impose production costs, but also disposal costs. With this, farmers can use irregular product waste to other forms, for example fertilizer for soil management so as to reduce production costs.

\section{RESEARCH METHODOLOGY}

The survey was conducted to farmers, the agricultural industry, and academics in agriculture in South Korea who know about the 6th order Industry policy. The sample selection is done by purposive sampling. The survey was conducted through interviews and filling out questionnaires Strengthness, Weakness, Opportunities, and Threats.

\section{RESULT AND DISCUSSION}

Indonesia's agriculture has prospective potentials, however, most of the actors are in their poverty. It indicates that government have not yet empowered the farmers but also the agriculture. The development of agriculture in the past has several weaknesses including focusing more on agriculture business, weak macro policy support, and centralistic approach. As a result, Indonesian agriculture are mostly dominated by small scale business, limited capital, simple technology, depending on the weather, local market, kinship employement causing agriculture involution, low access to technology, credit and market, and agriculture market with mono/oligopsony runs by bigger traders who might play the price [11]. In addition, there are problems inhibit the agriculture development in Indonesia such as uncontrolled land reform (converting agricultural areas to non-agricultural ones), low provisions for qualified seeds for farmers and fertilizers shortage during growing and planting season [12] [13].

The strength of Indonesia's agricultural system (Table 1) lies in its diverse agro-climate, which stretches from the West to the East with a lot of water potential to dry areas that allow livestock to benefit and crop production. The rainy season in Indonesia lasts for more than 6 months in most areas allowing the planting of various commercial crops such as cocoa, rubber, coffee and tea in quantities that can be exported; while the planting of staple crops such as maize, cassava, rice, sweet potatoes, fruit plants thrive in most areas. A simple, non-capital intensive native farming system supported by a large group of people whose main occupation is farming. The cost of farm laborers in Indonesia is quite low because a day's wages for farm laborers are around $\$ 10$. Over the years, Indonesian tertiary institutions with the Faculty / Department of Agriculture have increased with the increasing number of graduates trained in agriculture and related disciplines thus creating labor force for the agricultural industry. Indonesia as a nation has been fortunate because it 
enjoys free trade relations with most countries in the world with high demand for its agricultural products. The foregoing may be the reason for the interest shown over the years by a number of international development agency organizations.

Table 1. The Strengths and Weakness of Agriculture System in Indonesia based on The 6th Order Industry Perspectives.

\begin{tabular}{|c|c|c|c|c|}
\hline & IFAS & Score & Mean & Value \\
\hline \multicolumn{5}{|c|}{ Strengths } \\
\hline 1 & Favorable agro ecological zones & 0.072 & 3.26 & 0.23 \\
\hline 2 & Indigenous farming system & 0.072 & 3.26 & 0.23 \\
\hline 3 & Large domestic and international market (free trade) & 0.071 & 3.21 & 0.23 \\
\hline 4 & Low labor cost & 0.073 & 3.28 & 0.24 \\
\hline 5 & Large pool of farmers & 0.072 & 3.26 & 0.23 \\
\hline 6 & Large pool of trained manpower in agriculture & 0.075 & 3.37 & 0.25 \\
\hline 7 & Support of international organizations & 0.076 & 3.42 & 0.26 \\
\hline \multicolumn{2}{|r|}{ Total } & 0.51 & & 1.68 \\
\hline \multicolumn{5}{|c|}{ Weaknesses } \\
\hline 1 & Obsolete equipment & 0.081 & 3.53 & 0.29 \\
\hline 2 & Unstable economic and agricultural policies & 0.066 & 2.88 & 0.19 \\
\hline 3 & Lack of incentives & 0.070 & 3.07 & 0.22 \\
\hline 4 & Largely small holders farmers, low skilled & 0.062 & 2.70 & 0.17 \\
\hline 5 & Poor infrastructure (storage, transport, etc.) & 0.048 & 2.09 & 0.10 \\
\hline 6 & Low value added products & 0.046 & 2.08 & 0.10 \\
\hline 7 & Poor marketing & 0.051 & 2.32 & 0.12 \\
\hline 8 & Lack of data/information & 0.060 & 2.60 & 0.16 \\
\hline & & 0.48 & & 1.33 \\
\hline \multicolumn{4}{|c|}{ The Difference in Strength and Weakness } & 0.35 \\
\hline
\end{tabular}

Apart from the great power inherent in Indonesia's agricultural system, its efficacy in contributing to national development is fraught with a number of factors. The development of sectoral services in Indonesia has been cited by various groups as the main contributor to the country's agricultural sector lags. The attention of the government and unfortunately the population is also from agriculture, due to the rapid increase and return with surplus funds from other sectors; there is high rural-urban migration, neglect of farmers. The average farmer in Indonesia must rely on machetes and hoes as his main tool in his small garden. This is a major weakness in today's world that is driven by technology, now we are talking about precision agriculture. The unstable nature of most government policies with regard to socio-economic and industrial development, is another major obstacle that must be faced by the agricultural sector. An example is the policy of cassava and rice production, which was left in the middle of the river so that many farmers suffered losses from unsold products. Do not miss is the effect of poor infrastructure facilities, e.g. poor road network, lack of transportation, storage facilities; all combined to worsen the agricultural landscape. Farmers are also not encouraged to add value to their agricultural products by means of quality, processing, packaging and marketing; this makes their products unable to compete in the international market.

Table 2. The Opportunities and Threats of Agriculture System in Indonesia based on The 6th Order Industry Perspectives

\begin{tabular}{|c|c|c|c|c|}
\hline \multirow{2}{*}{\multicolumn{2}{|c|}{$\begin{array}{c}\text { EFAS } \\
\text { Opportunities }\end{array}$}} & Bobot & Skor & \multirow[t]{2}{*}{ Nilai } \\
\hline & & & & \\
\hline 1 & Large domestic and international market & 0.098 & 2.93 & 0.29 \\
\hline 2 & Large pool of trained manpower in agriculture & 0.116 & 3.47 & 0.40 \\
\hline 3 & Abundance of raw materials for farm inputs & 0.107 & 3.19 & 0.34 \\
\hline 4 & Development and availability of improved planting materials & 0.119 & 3.43 & 0.41 \\
\hline 5 & Improved telecommunication systems & 0.094 & 2.81 & 0.27 \\
\hline \multicolumn{2}{|r|}{ Total } & $\mathbf{0 . 5 3}$ & & 1.70 \\
\hline \multicolumn{2}{|r|}{ Threats } & & & \\
\hline 1 & Inconsistencies in policies & 0.097 & 2.907 & 0.28 \\
\hline 2 & Frequent change of government & 0.122 & 3.651 & 0.45 \\
\hline 3 & Climate change & 0.081 & 2.817 & 0.23 \\
\hline 4 & Land degradation & 0.171 & 3.730 & 0.64 \\
\hline \multirow{2}{*}{\multicolumn{2}{|c|}{$\begin{array}{c}\text { Total } \\
\text { The Difference in Onnortunities and Threats }\end{array}$}} & 0.47 & & 1.60 \\
\hline & & & & 0.11 \\
\hline
\end{tabular}


The opportunities abound for Indonesia to bounce back to the place of calculation in the agricultural sector. These opportunities include but are not limited to: sufficient income from crude oil exports, which can be easily explored to rejuvenate the agricultural sector; large domestic and international market availability for most of its products and by-products such as cocoa, palm oil, cashew nuts, rubber, plantains / bananas, rice, hides and skins, cotton, peanuts. The production of agricultural inputs such as fertilizer can be increased with products from the petrochemical industry, thereby reducing fertilizer costs and thus becoming an additional cost for farmers. Unlike what was obtained about three decades ago, there has been a huge increase in telecommunications facilities on the internet, TV and print media; so that ordinary farmers can easily get information about their farming companies. All of this can be utilized to make a positive difference in the agricultural sector..

The drive towards revitalizing the agricultural sector in Indonesia may be threatened by climate change that is being experienced globally. This is likely to be increased by the high incidence of pests and diseases and the lack of proper management techniques. The effects of the above may be made clearer as a result of land degradation activities as indicated by [14] [15], that decisions on land use are made indiscriminately based on economic and political considerations, with little or no consideration for status biophysical soil. Oil exploration and other mining activities cannot be avoided from threats, especially in the eastern region where oil is being explored. The effects of the above factors may not be significant when side by side with frequent changes in government, administrators and policies, all of which erode the confidence of potential investors in agribusiness [16]. Religious and ethnic conflicts such as those which have been witnessed in the country and which have not been fully restricted pose a threat to the development of agriculture in the region as well.

The policy in Indonesia in terms of financial and marketing to reach the objectives of the $6^{\text {th }}$ Order Industry are in the form of regulation supporting the indicators. The regulation UU No 3 Year 2014 on Industry, Regulation N0 19 Year 2013 on farmers' protection, empowerment and and the regulation from the ministry of agriculture No, $32 /$ Permentan/Sr.230/6/2016 on the people credit in agricultural sectors $6^{\text {th }}$ Order Industry. Through the regulation, government can allocate funding or provide ease for private industry by the regulation of the establishment of agriculture insurance (UU No 19 Year 2013 pasal 37), and People Credit in Agricultute number 32/Permentan/Sr.230/6/2016. By the regulations, the Indonesian government has collaborated with Bank of Indonesia in terms of fundings for farmers by distributing credit with $7 \%$ interest rate per year.

The support through the regulation Number 19 Year 2013 pasal 48 give authorities for government and local government to empower farmers by developing the system and facilities for agriculture products such as building terminal for agrobusiness and developing system and the facilities closer to the consumers for physical transaction such as auctions, subscription, and market spot as well as contracts and future market.

Based on the exposition above, it is recognized that decrease of the farmers is not anymore shocking. Government's doubts, industrialization and absence of master plan has made agriculture referred to powerlessness in negotiation the products price. Consequently, farmers' low bargaining position causes difficulties to increase their income.

Since the contribution of agrobusiness and agriculture is important, despite the existence of population of agriculture, future conditions need breakthrough to create better impressions for agriculture along with the effort for maintaining food security and sovereignty in Indonesia. Such moments is expected to be manifested by the issue of Regulation N0 19 Year 2013 on Farmers' Protection and Empowerment. There are a tentang Perlindungan dan Pemberdayaan Petani. There are a lot of positive expectation to support the empowerment in the primary, secondary and tertiary sectors in the future. One of them is government's responsibility to provide funding for the protection and empowerment by establishing farmers' banks and financial institutions. The banks are established to distribute credit for farmers with ease of access, requirements of applications and fast procedures.

\section{CONCLUSION}

In conclusion, that Indonesia as a country endowed with natural, human and capital resources will state the obvious. Unfortunately, exploiting this great potential for agricultural development has been weakened by factors such as losing focus, misplaced priorities, and lack of encouragement for key players among others. However, opportunities abound in the country to revive and make agriculture its main economic sector, provided that efforts are directed to guide towards threatening issues such as land degradation, inconsistent policies, and the ability to protect investors. Therefore, policy support is needed that considers the marketing and financial levels of each region and the capacity of each actor in The Sixth Order Industry. The central government and local governments must build a support system and establish the scope of the objectives and means of the Sixth Order Industry policy in a large framework and apply the actual support process more flexibly.

\section{REFERENCES}

[1] World Bank. 2017. Indonesian Economic Quarterly. World Bank Group: December.

[2] Diaz-Bonilla, E., Reca, and L. 2000. Trade and Agroindustrialization in Developing Countries: Trends and Policy Impacts. Agricultural Economics 23 (3): 219-229. 
[3] Hidaka, Ken. 2011. The business system and the development mechanism to support Sixthindustrialization in agricultural and fishery village. Kinki University

[4] Elias, Stephen \& Clare Noone, 2011. The Growth and Development of the Indonesian Economy, RBA Bulletin, Reserve Bank of Australia, pages 33-43, December.

[5] Kim Yong-lyoul, Kim Tae-gon, and Heo Joonyung. 2014. 6th Industrialization and Policies of Agriculture in Korea. FANEA Symposium.

[6] Liu Jin. 2014. 6th Industrialization of Agriculture in China: Development and Evolution. FANEA Symposium.

[7] Nakano, Ken. 2016. The effort of sixthindustrialization of Chinese mushroom production by using refrigerated containers. The Ritsumeikan Economic Review: Vol. 64 No. 3.

[8] Higenori, Kobayashi, Yurie Koshiba, Megumi Ohashi, And Akiko Tabata. 2014. The Current Situation of the 6th Industrialization in Japan and Related Policies. FANEA Symposium.

[9] Briones, Roehlano and Jesus Felipe. 2013. Agriculture and Structural Transformation in Developing Asia: Review and Outlook. ADB Economics Working Paper Series.

[10] Tsakok, I. 2011. Success in Agricultural Transformation: What it Means and What Makes it Happen. New York: Cambridge University Press.

[12] Kwon, H.J. \& Kim, W.R. 2015. The evolution of cash transfers in Indonesia: policy transfer and national adaptation. Asia and the Pacifi Policy Studies, 2: 425-440

[13] OECD. 2015. Indonesia policy brief (available at https:/www.oecd.org/policy-briefs/indonesiaagriculture-improving-food-security.pdf).

[14] Fuglie, Keith O. 2004. "Productivity Growth in Indonesian Agriculture, 1961-2000." Bulletin of Indonesian Economic Studies 40 (2): 209-25 in Armas, B.E. et. al. (2010). Agriculture Public Spending and Growth: The Example of Indonesia. Economic Premise No. 9, April 2010. World Bank

[15] Arifin, Bustanul. 2013. On the Competitiveness and Sustainability of the Indonesian Agricultural Export Commodities. ASEAN Journal of Economics, Management and Accounting

[16] ADB (Asian Development Bank). 2015. Summary of Indonesia's Agriculture, Natural Resources, and Environment Sector Assessment. ADB Papers on Indonesia No. 8, October 2015. Mandaluyong City, Philippines (available at https://www.adb.org/sites/default/fies/publication/1 77036/ino-paper-08-2015.pdf) 